\title{
The applicability of the gland/wall ratio (Reid-Index) to clinicopathological correlation studies
}

\author{
M OBERHOLZER, P DALQUEN, M WYSS, AND H P ROHR
}

From the Department of Pathology and the Department of Internal Medicine, University of Basle, Basle, Switzerland

Oberholzer, M, Dalquen, P, Wyss, M, and Rohr, H P (1978). Thorax, 33, 779-784. The applicability of the gland/wall ratio (Reid-Index) to clinicopathological correlation studies. We studied at necropsy the bronchi of 49 subjects whose lung function had been measured during life. In each case the glands were examined in three bronchi by measuring the gland/wall ratio (Reid-Index) and by point-counting. The results of the two methods were compared: the data of the gland/wall ratio were normally distributed while those of the volume density established by point-counting were not. Gland/wall ratio and volume density of glands correlated moderately $\left(R_{S p}=0.524\right)$. The function between them was not linear, in contrast with that between gland/wall ratio and gland thickness. The stereological background of these functions is discussed. In 34 subjects without restrictive lung disease $F E V_{1}$ correlated inversely with the volume density of glands $\left(R_{S p}=-0.396\right)$, but not with the gland/wall ratio (Reid-Index) $\left(R_{S p}=-0 \cdot 243\right)$. This discrepancy probably results from the different distribution of the data obtained by the two methods and from the non-linear function between them. These findings indicate that the gland/wall ratio (Reid-Index) is less applicable to clinicopathological correlations than the volume density of glands established by point-counting.

The ratio gland/wall thickness measured between cartilage and epithelial basement membrane was introduced by Reid (1960) as a measurement of chronic bronchitis. Dunnill (1962) suggested the point-counting method for measurement of the glands in chronic bronchitis. This method has some advantages:

(1) Glands and other compartments of the bronchial wall can be measured simultaneously.

(2) All glands of a section of bronchus are covered by the measurement.

(3) Results are not influenced by wrinkling of the bronchial mucosa.

Both methods have been applied to clinicopathological studies. The results, especially those of correlations between Reid-Index and $\mathrm{FEV}_{1}$ (forced expiratory volume in 1 second) are conflicting (Bath et al, 1968; Boushy et al, 1970; Thurlbeck et al, 1970; Lyons et al, 1972). Some authors have discussed the Reid-Index as "yardstick of chronic bronchitis" (Thurlbeck and Angus, 1964; 1967; Hartung and Meyer-Carlstädt, 1968; Dunnill et al, 1969; Bedrossian et al, 1971; Takizawa and Thurlbeck, 1971; Panel on Pathology of the Medical Research Council
Committee on Research into Chronic Bronchitis, 1975). The purpose of this study is to scrutinise the applicability of Reid-Index and volume density of bronchial glands established by point-counting to clinicopathological correlations.

\section{Material and methods}

Lungs taken at necropsy from 41 men and 8 women were studied. The mean age of the subjects was 65.4 (38-81) years. Forty-five had had lung function tests within an average of 18 months before death. We have unpublished evidence that this time-lag does not affect correlations between volume density of glands and lung function tests. The tests included measurements of total lung capacity (TLC), vital capacity (VC), residual volume (RV), $\mathrm{FEV}_{1}$ as $\% \mathrm{VC}$ or as \% of predicted value, and resistance of airways (Raw). In 34 cases TLC was $\geqslant 90 \%$ of predicted. Only these subjects were admitted to the clinicopathological correlations because the $\mathrm{FEV}_{1}$ data are only relevant in the absence of restrictive lung disease. The lungs were fixed in the inflated state by transbronchial instillation of $4 \%$ formalin in saline. Bronchi were 
sampled from three well-defined sites in the bronchial tree (upper lobe, apical segment of lower lobe, and lower lobe beneath the carina of the upper segmental bronchus (fig 1)). Histological preparations and
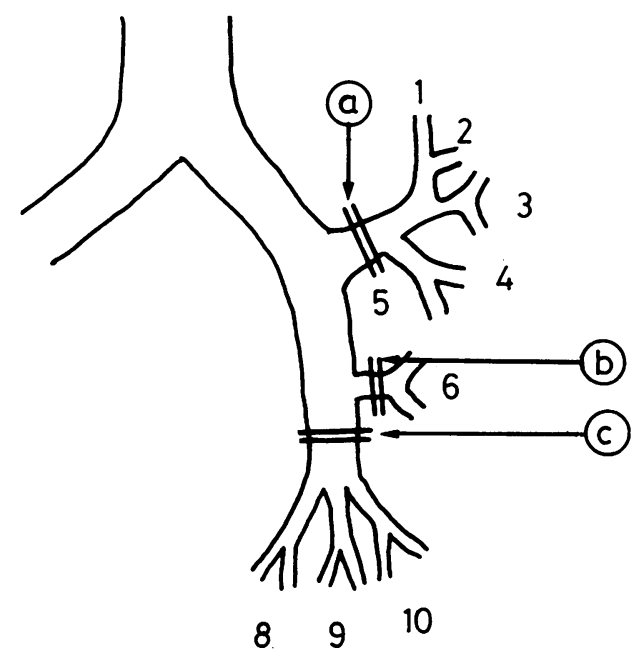

Fig 1 Bronchus samples for morphometry from three sites in bronchial tree: A: upper lobe, B: apical segment of lower lobe, $C:$ lower lobe beneath apical segmental bronchus.

morphometric procedures have been described in detail by Oberholzer et al (1977). In each of the three bronchi the glands were measured by the Reid-Index and by point-counting. All morphometric measurements were done at magnification $\times 50$ by means of Reichert's projection microscope "Visopan." The measurements of the three bronchi from each subject were averaged. The following correlations were studied:

$$
\begin{aligned}
& A \quad=f(R) \\
& V_{V(G L / B S T)}=f(R) \\
& A \quad=f\left(V_{V(G L / B S T)}\right) \\
& \mathrm{R} \quad=\mathrm{f}\left(\mathrm{FEV}_{\mathbf{1}}\right. \text { in \% VC) } \\
& R=f\left(F E V_{1} \text { in } \% \text { of predicted value }\right) \\
& \mathrm{V}_{\mathrm{V}(\mathrm{GL} / \mathrm{BST})}=\mathbf{f}\left(\mathrm{FEV}_{1}\right. \text { in \% VC) } \\
& V_{V(G L / B S T)}=f\left(F E V_{1}\right. \text { in \% of predicted value) }
\end{aligned}
$$

(R: Reid-Index, A: bronchial gland thickness, $\mathrm{V}_{\mathrm{V} \text { (GL/BST): volume density of bronchial glands }}$ related to $1 \mathrm{~cm}^{3}$ bronchial wall tissue without cartilage (BST)).

For calculations a Hewlett-Packard 9815 A desk computer was used. The statistical analyses included tests of normal distribution and linearity as well as histograms of all measurements, age distribution, and distribution of the period between lung function tests and death. Curve fitting was done by the method of Sachs (1974). For all calculations of correlations
Spearman's rank correlation coefficient $\left(R_{s p}\right)$, which is independent of distribution, was calculated.

\section{Results}

The Reid-Index showed a normal distribution. The

\begin{tabular}{|c|c|c|c|c|}
\hline Group & Measuremen & Mean & Standard & Median \\
\hline $\begin{array}{l}\text { All } 49 \\
\text { subjects }\end{array}$ & $\begin{array}{l}\text { Reid Index } \\
\text { VV(GL/BST) } \\
\text { gland } \\
\text { thickness } \\
\text { (cm) }\end{array}$ & $\begin{array}{l}0.560 \\
0.250\end{array}$ & $\begin{array}{l}0.105 \\
0.080\end{array}$ & $\begin{array}{l}0.563 \\
0.234\end{array}$ \\
\hline $\begin{array}{l}34 \text { subjects } \\
\text { without } \\
\text { restriction }\end{array}$ & $\begin{array}{l}\text { Reid-Index } \\
\text { VV(GL/BST) } \\
\text { FEV } \\
\text { (in } \% \text { VC) } \\
\text { FEV } \\
\text { (in } \% \text { of } \\
\text { predicted va }\end{array}$ & $\begin{array}{l}0.573 \\
0.248 \\
51 \cdot 3 \\
60 \cdot 1 \\
\\
\text { ue) }\end{array}$ & $\begin{array}{l}0.113 \\
0.084 \\
17 \cdot 0 \\
\\
26 \cdot 2\end{array}$ & $\begin{array}{l}0 \cdot 577 \\
0 \cdot 232 \\
52 \cdot 0 \\
\\
57 \cdot 5\end{array}$ \\
\hline
\end{tabular}
volume density of bronchial glands, however, was non-normally distributed (table 1).

Table 1 Mean, standard deviation and median of ReidIndex, volume density of bronchial glands related to $1 \mathrm{~cm}^{3}$ bronchial wall tissue without cartilage $\left(V_{V(G L / B S T)}\right)$, gland thickness, and FEV 1 for the two groups analysed

There was a moderate correlation between ReidIndex and volume density of bronchial glands (fig 2; table 2). The following equation was found by curve fitting analysis:

$$
\mathrm{R}=0.820 \frac{\mathrm{V}_{\mathrm{V}(\mathrm{GL} / \mathrm{BST})}}{\mathrm{V}_{\mathrm{V}(\mathrm{GL} / \mathrm{BST})}+0 \cdot 118}
$$

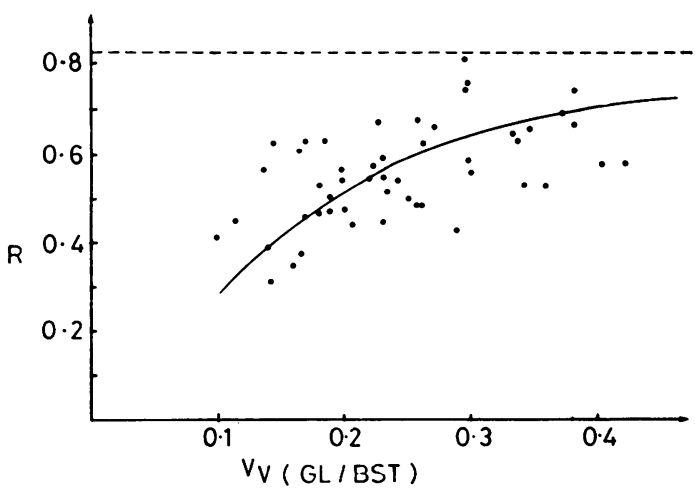

Fig 2 Correlation between volume density of bronchial glands related to $1 \mathrm{~cm}^{3}$ bronchial wall tissue without cartilage $\left(V_{V(G L / B S T)}\right)$ and Reid-Index $(R): R_{S p}=0.524$, $N=49,2 \mathrm{P}<0.001$. 
Table 2 Correlation coefficients (Spearman rank correlation) between Reid-Index and volume density of bronchial glands $\left(V_{V(G L / B S T)}\right)$, Reid-Index and gland thickness, and between volume density of bronchial glands and gland thickness

\begin{tabular}{lllll}
\hline Correlation & $R_{S p}$ & $N$ & $2 \mathrm{P}$ \\
\hline Reid-Index $=\mathrm{f}(\mathrm{Vv}$ (GL/BST) & 0.5240 & 49 & $<0.001$ \\
Reid-Index & $=\mathrm{f}($ gland thickness) & 0.6810 & 49 & $<0.001$ \\
Vv(GL/BST) & $=\mathrm{f}($ gland thickness) & 0.6026 & 49 & $<0.001$ \\
\hline
\end{tabular}

As expected, Reid-Index correlated with gland thickness A (fig 3; table 2). The following equation between the two variables Reid-Index $(R)$ and gland thickness (A) was found by curve fitting analysis:

$$
\mathrm{R}=0.866 \frac{\mathrm{A}}{\mathrm{A}+0.012}
$$

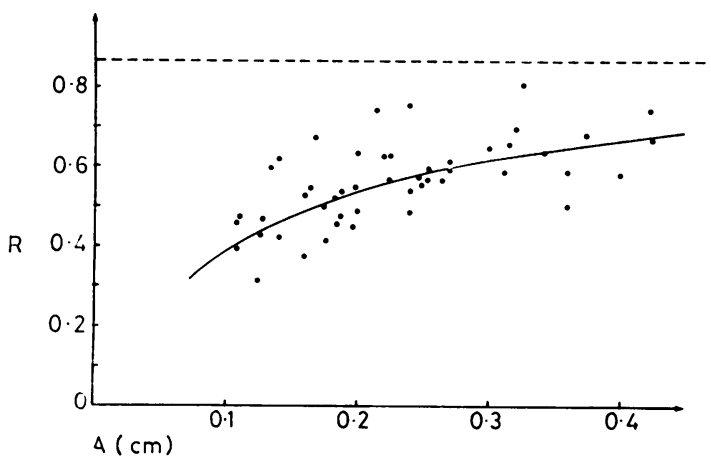

Fig 3 Correlation between gland thickness $(A)$ and gland/wall ratio (Reid-Index) $(R): R_{S p}=0.681, N=49$, $2 \mathrm{p}<0.001$.

There was a linear regression between volume density of glands and gland thickness (A) (fig 4; table 2). The formula of this regression line was:

$$
\mathrm{V}_{\mathrm{V}(\mathrm{GL} / \text { B S T })}=0 \cdot 117+5 \cdot 6 \mathrm{~A}
$$

The Reid-Index correlated neither with $\mathrm{FEV}_{1}$ as $\%$ VC nor with $\mathrm{FEV}_{1}$ as \% of predicted value (table 3).

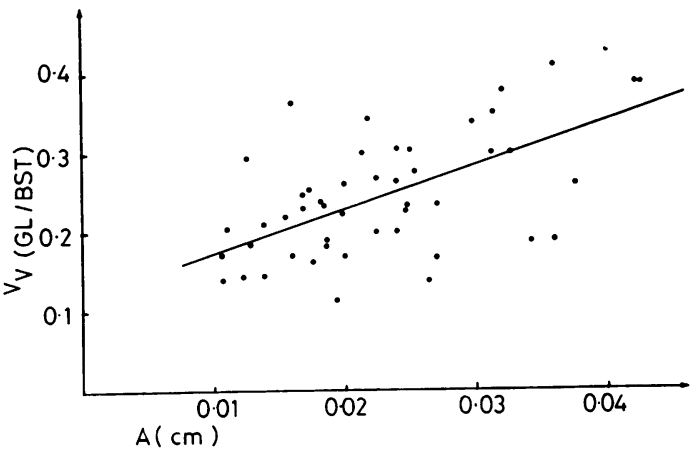

Fig 4 Correlation between gland thickness $(A)$ and volume density of bronchial glands related to $1 \mathrm{~cm}^{3}$ bronchial wall tissue without cartilage $\left(V_{V(G L / B S T)}\right)$ $R_{S p}=0.603, N=49,2 \mathrm{P}<0.001$.

The volume density of bronchial glands

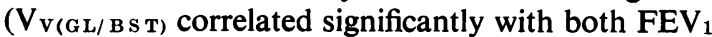
as $\% \mathrm{VC}$ and with $\mathrm{FEV}_{1}$ as $\%$ of predicted value (fig 5 ; table 3 ).

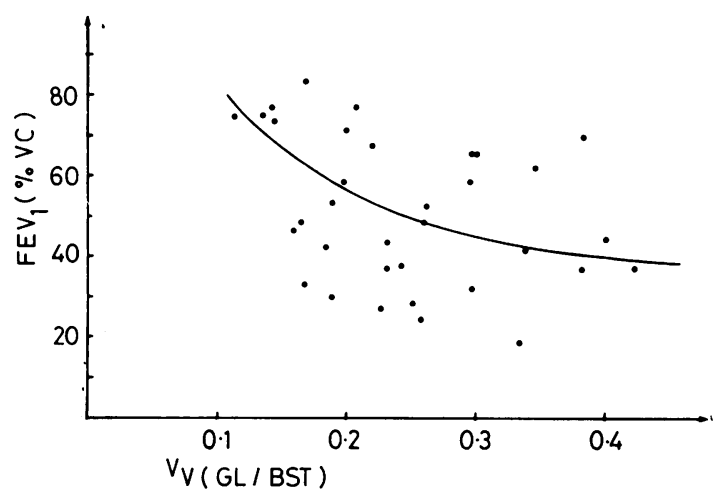

Fig 5 Correlation between volume density of bronchial glands related to $1 \mathrm{~cm}^{3}$ bronchial wall tissue without cartilage $\left(V_{V(G L / B S T)}\right)$ and $F E V_{1}($ as $\% V C): R_{S p}=$ $-0.396, N=34,2 \mathrm{P}<0.05$.

Table 3 Correlation coefficients (Spearman rank correlation) between FEV 1 and volume density of

\begin{tabular}{|c|c|c|c|c|}
\hline \multicolumn{2}{|l|}{ Correlations } & \multirow{2}{*}{$\begin{array}{l}R_{S p} \\
-0.3962 \\
-0.4625\end{array}$} & \multirow{2}{*}{$\begin{array}{l}N \\
34 \\
34\end{array}$} & \multirow{2}{*}{$\begin{array}{l}2 \mathrm{P} \\
<0.05 \\
<0.01\end{array}$} \\
\hline $\begin{array}{l}\mathrm{FEV}_{1} \text { (as } \% \text { VC) } \\
\mathrm{FEV}_{1} \text { (as \% of predicted value) }\end{array}$ & $\begin{array}{l}=f(V v(G L / B S T) \\
=f(V V(G L / B S T)\end{array}$ & & & \\
\hline $\begin{array}{l}\mathrm{FEV}_{1} \text { (as \% VC) } \\
\mathrm{FEV}_{1} \text { (as \% of predicted value) }\end{array}$ & $\begin{array}{l}=\mathrm{f}(\text { Reid-Index }) \\
=\mathrm{f} \text { (Reid-Index) }\end{array}$ & $\begin{array}{l}-0.2426 \\
-0.2710\end{array}$ & $\begin{array}{l}34 \\
34\end{array}$ & $\begin{array}{l}>0 \cdot 10 \\
>0 \cdot 10\end{array}$ \\
\hline
\end{tabular}
bronchial glands $\left(V_{V(G L / B S T)}\right)$, and between FEV 1 and Reid-Index 


\section{Discussion}

THEORETICAL BASIS OF THE CORRELATION BETWEEN REID-INDEX AND VOLUME DENSITY OF BRONCHIAL GLANDS

The Reid-Index $(R)$ has been defined as the proportion of the two lengths gland thickness $(A)$ to bronchial wall thickness $(B)$ between cartilage and epithelial basement membrane (Reid, 1960). The bronchial wall thickness (B) is composed of gland thickness (A) and thickness (C) of remaining tissue:

$$
\mathbf{R}=\frac{\mathbf{A}}{\mathbf{B}}=\frac{\mathbf{A}}{\mathrm{A}+\mathbf{C}}
$$

Empirically we found that $\mathbf{R}$ depends on $\mathbf{A}$ according to eq 2 . From this equation can be concluded that $C$ is constant and amounts to 0.012 in the three studied central bronchi. Thurlbeck and Angus (1964) made similar observations in central and subsegmental

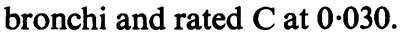

The Reid-Index as proportion of two lengths can also be written by stereological symbols as follows:

$$
R=\frac{L_{(G L)}}{L_{(B S T)}}=\frac{L_{(G L)}}{L_{(G L)}+L_{(C)}}
$$

According to Rosiwal's stereological axiom (Rosiwal, 1898) the proportion of two lengths corresponds to the proportion of two volumes, provided that multiple measurements have been done:

$$
\frac{L_{(i)}}{L_{(T)}}=\frac{V_{(i)}}{V_{(T)}}
$$

where (i) refers to structure $\mathrm{i}$ and $(\mathrm{T})$ to a reference structure. Therefore the Reid-Index can also be written:

$$
R \sim \frac{V_{(G L)}}{V_{(G L)}+V_{(C)}}
$$

$\mathrm{R}$ is not exactly the same as the volume proportion given in this equation because it is merely based on one measurement.

The ratio $V_{(\mathrm{I})} / \mathrm{V}_{(\mathrm{T})}$ in eq 6 is defined as volume density:

$$
\frac{V_{(i)}}{V_{(T)}}=V_{V(i / T)}
$$

$V_{(i)}$ is the volume of structure (i), $V_{(T)}$ is the reference volume. The volume densities of bronchial tissue compartments are related to the reference volume $1 \mathrm{~cm}^{3}$ bronchial wall tissue without cartilage $\left(\mathrm{V}_{(\mathrm{B} \mathrm{S} \mathrm{T})}\right)$ (cf Oberholzer et al, 1977):

$$
\mathrm{V}_{\mathbf{V}(\mathbf{i} / \text { BS T })}=\frac{\mathrm{V}_{(\mathrm{i})}}{1 \mathrm{~cm}^{3} \mathrm{~V}_{(\text {BST })}}
$$

As $1 \mathrm{~cm}^{3} \mathrm{~V}_{(\mathrm{BST})}$ is constant the equation (9) can be transformed into:

$$
\mathrm{V}_{\mathbf{V}(\mathbf{i} / \text { B S T })}=\frac{\mathrm{V}_{(\mathbf{i})}}{\mathrm{K}}
$$

(K: constant)

or

$$
\left.\mathbf{V}_{(\mathbf{i})}=\mathbf{K} \times \mathbf{V}_{\mathbf{V}(\mathbf{i} / \mathbf{B} \text { S }} \mathbf{T}\right)
$$

Thus the real volumes in equation (7) can be replaced $\vec{\circ}$ by the corresponding volume densities:

$$
R \sim \frac{\mathrm{V}_{\mathrm{V} \text { (GL/BST) }}}{\mathrm{V}_{\mathrm{V} \text { (GL/BST) }}+\mathrm{V}_{\mathrm{V} \text { (C/BST) }}}
$$

$\mathbf{R}$ can be equated with the proportion of volume densities by introduction of the constant factor $Q$ :

$$
\mathbf{R}=\mathbf{Q} \frac{\mathbf{V}_{\mathbf{V}(\mathrm{GL} / \mathrm{BST})}}{\mathbf{V}_{\mathbf{V} \text { (GL/BST) }}+\mathbf{V}_{\mathbf{V}(\mathrm{C} / \mathrm{BST})}}
$$

Empirically we found that $Q$ amounts to 0.820 and $\mathrm{V}_{\mathrm{v} \text { (C/BS T) }}$ to the constant value $0 \cdot 118$ (eq 1). Microscopical observations support that $V_{v(C / B S T)}$ is a constant item: in chronic bronchitis the bronchial wall tissue remains almost unchanged. (Thickening of bronchial muscles has little effect because they $\vec{\varphi}$ occupy only a small portion of the bronchial wall tissue.)

From equation (4) and (12) follows:

$$
\frac{A}{A+C} \sim \frac{V_{V(G L / B S T)}}{V_{V(G L / B S T)}+V_{V(C / B S T)}}
$$

or

$$
\mathrm{V}_{\mathrm{V}(\mathrm{GL} / \mathrm{BST})} \sim \frac{\mathrm{V}_{\mathrm{V}(\mathrm{C} / \mathrm{BST})} \times \mathrm{A}}{\mathrm{C}}
$$

or

$$
\mathrm{V}_{\mathbf{V}(\mathrm{GL} / \mathrm{BST})}=\mathrm{Z} \frac{\mathrm{V}_{\mathrm{V}(\mathrm{C} / \mathrm{BST})} \times \mathrm{A}}{\mathrm{C}}
$$

The constant factor $\mathrm{Z}$ has also to be introduced, as the Reid-Index is based on a single measurement. The equations (1) and (2) found empirically show that $\mathrm{V}_{\mathrm{V} \text { (C/BST) }}$ and $\mathrm{C}$ are constant. Therefore a linear regression must exist between $\mathrm{V}_{\mathrm{V}(\mathrm{GL} / \mathrm{BST} \text { ) and }}$ A. This has been confirmed by our results (eq 3, fig 4). The item $\times 0.117$ in equation (3) may be the consequence of errors in measurements.

The volume density of bronchial glands is equal to a mean "Reid-Index" $(R$ '). This is very similar to the original Reid-Index (R), because according to the stereological principles of Delesse (1847) and Rosiwal (1898) the measurement of volume density of bronchial glands corresponds to multiple measurements of the two lengths, gland thickness $\left(A_{x}\right)$ and wall thickness $\left(B_{\mathbf{x}}\right)$ :

$$
R^{\prime}=\frac{1}{N} \sum_{x=1}^{N} \frac{A_{x}}{B_{x}}=\frac{1}{N} \sum_{x=1}^{N} \frac{L_{(G L)_{x}}}{L_{(B S T)_{x}}}=V_{v(G L / B S T)}
$$

From fig 2 it can be seen that the original Reid-Index (R) established by a single measurement is generally 
higher than the volume density of bronchial glands. This can be explained as follows: in morphometric calculations of the reference volume $1 \mathrm{~cm}^{3}$ bronchial wall tissue without cartilage $\left(\mathrm{V}_{(\mathrm{B} S \mathrm{~T})}\right)$ the portion of cartilage is always subtracted from the bronchial wall tissue. By this subtraction the cartilage is theoretically transformed into a small belt surrounding the whole bronchus (CRT', fig 6a). That means that the distances $B_{\mathbf{x}}$ (eq 17) become larger than the distance $B$ of the original Reid-Index (R) (fig 6b). Thus the ratios $A_{x} / B_{x}$, and the mean of these ratios as well as the volume density of bronchial glands become smaller than the original Reid-Index (R).

\section{INCONSISTENCIES BETWEEN REID-INDEX AND}

BRONCHIAL GLAND VOLUME DENSITY

There are two inconsistencies between the two

(a)
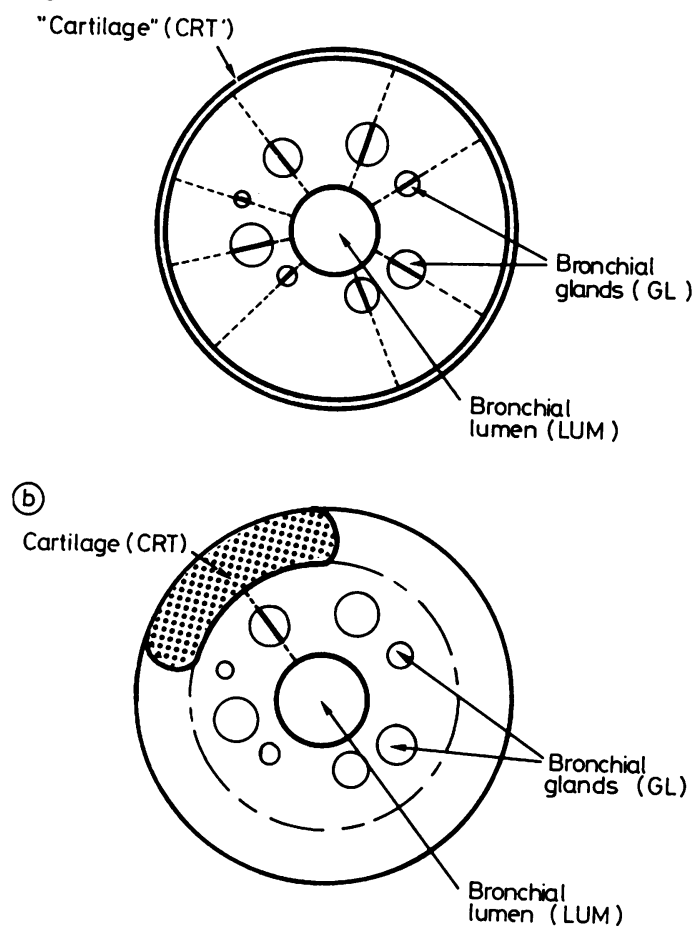

Fig 6(a) and 6(b) Illustration to equation (17) which gives the morphometrical relations between point-counting and gland/wall ratio (Reid-Index): By point-counting all glands are taken into account and cartilage is theoretically transformed by subtraction from entire bronchial wall into a small belt surrounding the bronchus. Thus thickness $B_{x}$ of the bronchial wall tissue without cartilage must always be larger than corresponding length $B$ of original ReidIndex, which is measured between cartilage and epithelial basement membrane. morphometric measurements Reid-Index and volume density of bronchial glands:

(1) The Reid-Index is normally distributed within a group of necropsy cases whereas the volume density of glands established by point-counting is non-normally distributed. These observations are in accordance with the findings of others (Thurlbeck and Angus, 1964; 1967; Hartung and Meyer-Carlstädt, 1968). Thurlbeck and Angus (1967) did not study the distribution of the volume density of bronchial glands but they established a non-normal distribution of the gland thickness $A$.

(2) The Reid-Index ( $R$ ) is generally higher than the volume density of bronchial glands related to $1 \mathrm{~cm}^{3}$ bronchial wall tissue without cartilage (fig 2). Similar observations were made by Hartung and Meyer-Carlstädt (1968). They found that the ratio gland thickness/wall thickness established by a single measurement (Reid-Index) was always higher than the ratio gland area/area of bronchial tissue without cartilage, which is equivalent to the volume density of bronchial glands (Glagoleff, 1933). The difference between the two ratios becomes smaller if a mean ratio gland thickness/wall thickness is established by multiple measurements at various sites of the bronchial section (Hartung and Meyer-Carlstädt, 1968). Therefore Alli (1975) proposed multiple measurements of the ratio gland thickness/wall thickness by a radial intercept method. He found a close correlation between the results of this method and those of point-counting. This close correlation is not surprising if the stereologic axioms on which point-counting is based are considered.

\section{APPLICABILITY OF THE REID-INDEX (R) TO CLINICOPATHOLOGICAL STUDIES}

Our example of practical application of the ReidIndex (R) and of point-counting to clinicopathological correlations showed a significant correlation between the volume density of bronchial

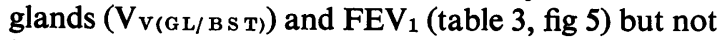
between the Reid-Index (R) and FEV 1 (table 3). One of the reasons of this discrepancy might be the divergent distribution of the data of the two measurements (table 1). Another reason seems to be the nonlinearity of the regression between Reid-Index (R) and volume density of bronchial glands $\left(\mathrm{V}_{\mathrm{V} \text { (GL/B S T) }}\right)$. Figure 2 shows that at high volume densities of glands the curve flattens out and approximates to an asymptote corresponding to a Reid-Index (R) of $0 \cdot 820$. Thus at high volume densities of bronchial glands the Reid-Index is increasingly insensitive, so 
that correlations between clinical measurements and gland thickness may be blurred.

In conclusion, stereological considerations have shown that the volume density of bronchial glands and the gland/wall thickness ratio (Reid-Index) are comparable measurements. Comparison of both, however, has shown that the Reid-Index is less sensitive at high gland volumes because the function between Reid-Index and gland thickness is not linear, and therefore, for clinicopathological studies, only the point-counting method and the assessment of volume density of bronchial glands should be used.

We thank Professor H Herzog, Department of Medicine, University of Basel, for leaving the clinical data.

\section{References}

Alli, A F (1975). The radial intercepts method for measuring bronchial mucus gland volume. Thorax, 30, 687-692.

Bath, J C, and Yates, P A (1968). Clinical and pathologic correlations in chronic airways obstruction -observation on patients with pulmonary resection. In Current Research in Chronic Airways Obstruction. Ninth Aspen Conference, pp 293-308. US Public Health Service Publication 1717, Washington.

Bedrossian, C W M, Anderson, A E, and Foraker, A G (1971). Comparison of methods for quantitating bronchial morphology. Thorax, 26, 406-408.

Boushy, S F, Helgason, A H, Billing, D M, and Gyorky, F G (1970). Clinical, physiologic, and morphologic examination of the lung in patients with bronchogenic carcinoma and the relation of the findings to postoperative deaths. American Review of Respiratory Disease, 101, 685-695.

Delesse, M A(1847). Procédé méchanique pour déterminer la composition des roches. Compte Rendus de l'Académie des Sciences (Paris), 25, 544-545.

Dunnill, M S (1962). Quantitative methods in the study of pulmonary pathology. Thorax, 17, 320-328.

Dunnill, M S, Massarella, G R, and Anderson, J A (1969). A comparison of the quantitative anatomy of the bronchi in normal subjects, in status asthmaticus, in chronic bronchitis, and in emphysema. Thorax, 24, 176-179.

Glagoleff, A A (1933). On the geometrical methods of quantitative mineralogic analysis of rocks. Transactions of the Institute of Economic Mineralogy (Moscow), no 59.

Hartung, W, and Meyer-Carlstädt, D (1968). Reid's index in the diagnosis of chronic bronchitis. Beiträge zur pathologischen Anatomie und zur allgemeinen Pathologie, 137, 85-98.

Lyons, J P, Ryder, R, Campbell, H, and Gough, J (1972). Pulmonary disability in coal workers' pneumoconiosis. British Medical Journal, 1, 713-716.

Oberholzer, M, Dalquen, P, Huber, M, and Rohr, H P (1977). Stereology, a complement to respiration research. Bronchusmorphometry: methodology and base line data. Microscopica Acta, 79, 205-223.

Reid, L (1960). Measurement of the bronchial mucous gland layer: a diagnostic yardstick in chronic bronchitis. Thorax, 15, 132-141.

Report by Panel on Pathology of the Medical Research Council Committee on Research into Chronic Bronchitis (1975). Quantitative assessment of chronic non-specific lung disease at necropsy. Thorax, 30, 241-251.

Rosiwal, A (1898). Ueber geometrische Gesteinsanalysen. Ein einfacher Weg zur ziffermässigen Feststellung des Quantitätsverhältnisses der Mineralbestandteile gemengter Gesteine. Verhandlungen des KöniglichKaiserlichen Geologischen Reichsamtes (Wien), p 143.

Sachs, L (1974). Angewandte Statistik, 4th edn. SpringerVerlag, Berlin.

Takizawa, T, and Thurlbeck, W M (1971). A comparative study of four methods of assessing the morphologic changes in chronic bronchitis. American Review of Respiratory Disease, 103, 774-783.

Thurlbeck, W M, and Angus, G E (1964). A distribution curve for chronic bronchitis. Thorax, 19, 436-442.

Thurlbeck, W M, and Angus, G E (1967). The variation of Reid index measurements within the major bronchial tree. American Review of Respiratory Disease, 95, 551-555.

Thurlbeck, W M, Henderson, J A, Fraser, R G, and Bates, D V (1970). Chronic obstructive lung disease. A comparison between clinical, roentgenologic, functional, and morphologic criteria in chronic bronchitis, emphysema, asthma, and bronchiectasis. Medicine (Baltimore), 49, 81-145.

Requests for reprints to: Dr P Dalquen, Institut für $\widetilde{\mathcal{S}}$ Pathologie, Schönbeinstrasse 40, CH-4000 Basel, N Switzerland. 